\title{
IMPACT ON PROFIT, CASH FLOW, COMPANY SIZE AND FINANCIAL DISTRESS
}

${ }^{123}$ Liza Zuhrianto, Sri Mulyani, Ratna Wijayanti Daniar Paramita

Departement of Accountinng, STIE Widya Gama Lumajang ${ }^{13}$

IAI Sunan Kalijogo Jabung Malang ${ }^{2}$

Email: liyundira90@gmail.com

\section{A R T I C LE IN F O}

Date of entry:

12 Oktober 2019

Revision Date:

25 November 2019

Date Received:

15 Desember 2019

\begin{abstract}
A B S T R A C T
The purpose of this study was to determine the effect of earnings, cash flow, and firm size on the financial distress of manufacturing companies in the consumer goods industry sector listed on the Indonesia Stock Exchange in 2016-2018. This type of research is quantitative research. The type of data in this study is secondary data. Data analysis techniques used multiple linear regression analysis. This study uses a purposive sampling technique to get samples according to specified criteria. The number of samples selected based on the criteria in this study is 32 companies with a population of 38 manufacturing companies in the consumer goods industry sector, which are listed on the Indonesia Stock Exchange in 2016-2018. The results showed that profits measured using a return on assets affect financial distress
\end{abstract}

Keywords: Profit, Cash Flow, Company Size, and Financial Distress.

Cite this as: Zuhrianto, L., Mulyani, S., Paramita, R. W. D. (2020). IMPACT ON PROFIT, CASH FLOW, COMPANY SIZE AND FINANCIAL DISTRESS. Assets : Jurnal Ilmiah Ilmu Akuntansi, Keuangan dan Pajak, 4(1), 21-26.

\section{INTRODUCTION}

In the current era of globalization, business competition is becoming tougher, coupled with investors who are more careful in choosing and making decisions where they will invest. Not all companies are able to compete, and there are also some companies that experience conditions of financial difficulty due to increasingly fierce business competition. Therefore, business development is one of the important things that must be considered by entrepreneurs. One problem that must be watched by all companies is Financial Distress. According to Atmaja (2008: 258) in Rahayu and Sopian (2016) states that financial distress is a condition in which a company is experiencing financial difficulties and is threatened with bankruptcy. The choice of manufacturing companies in the consumer goods industry sector in this study is due to the consumer goods industry sector companies producing basic necessities most needed by the public along with the increasing population in Indonesia. Manufacturing companies in the consumer goods industry sector are companies engaged in food and beverage, cosmetics, pharmaceuticals, cigarettes, and household appliances. Companies engaged in the consumer goods industry sector have high operating activities, causing the company to be able to manage each of its activities in order to optimize its resources to generate profits so as to minimize the risk of financial distress in the company. 
Various financial statement information can be a determinant indicator of financial distress, including profit and loss, cash flow, and company size. According to Natariasari and Indarto (2014), operational accounting income is defined as the difference between realized revenue from transactions that occur during a period and the costs associated with that income. The income statement is used by investors to determine the company's ability to pay dividends because the amount of dividends that will be obtained by investors depends on how much the company's profit. The income statement of a company will be listed as the company's achievement within a certain period. The higher the profit generated by a company shows that the company's performance is getting better, so the lower the possibility of the company experiencing financial distress. Conversely, the lower profit shows that the company's performance is not good, where the company is not able to optimize its resources to produce profits so that profits decline. This can give a negative signal to investors because the possibility of financial distress for the company will increase (Kusuma \& Sumani, 2017).

Cash flow is a report that provides relevant information about cash receipts and cash disbursements of a company in a certain period by classifying transactions in operating, financing, and investment activities (Sofyan Syafri Harahap, 2015: 257) in (Laksmita, 2016: 3). The cash flow statement is used by creditors to see a company's ability to pay off its debts. Cash flow information can be used in predicting a company's financial distress. The higher the ratio results calculated from the cash flow statement, the lower the likelihood of financial distress due to a large cash amount shows that the company will be able to pay its obligations, and the company is not experiencing financial distress. Vice versa, Furthermore, company size is a scale that can classify large and small companies according to various ways, namely total assets, average sales level, stock market value (Machfoedz, 1994) in (Rahayu and Sopian, 2016). The size of the company can be seen from how large the total assets owned by the company, where if the company has a large number of total assets, the tendency of companies to experience financial distress becomes smaller and the company will be able to pay off its obligations (Putri and merkusiwati, 2014: 96 ).

Research conducted by Natariasari and Indarto (2014) concluded that earnings were more significant in predicting financial distress than cash flow. Setiawan, Oemar, and Pranaditya (2016) also concluded that earnings have a significant effect on financial distress; cash flow has no significant effect on financial distress. While research conducted by Abdul Kadir (2014) in Frans Julius (2015) shows that earnings do not have a significant effect in predicting financial distress, cash flow has a significant influence in predicting financial distress. The results of the research by Fans of Julius (2015) support that earnings do not affect financial distress. Cash flow influences financial distress. Rahayu and Sopian (2016), in their research, concluded that the results of hypothesis testing for the size of the company simultaneously had a significant effect on financial distress. At the same time, the results of research conducted by Setiawan, Oemar, and Pranaditya (2016) show that company size has no significant effect on financial distress.

From a number of previous studies with earnings, cash flow, and company size variables on financial distress, namely Natariasari and Indarto (2014), Abdul Kadir (2014), Frans Julius (2015), Rahayu and Sopian (2016). From some of the results of the above studies that are still not consistent, the authors want to examine the effect of earnings, cash flow, and company size on a company's financial distress.

\section{METHODS}

This research uses quantitative research methods by looking for associative relationships. This study analyzes and tests the theory of the value of research variables using statistical methods to determine the relationship between these variables. The data in this study are in the form of financial statements in manufacturing companies in the consumer goods industry sector. The 
population of this study is all manufacturing companies in the consumer goods industry sector, which are listed on the Indonesia Stock Exchange (BEI) in 2016-2018 as many as 38 companies. Sampling using purposive sampling so that the number of samples obtained as many as 32 companies. The determination of this research sample considers the following criteria: 1) Companies listed on the Indonesia Stock Exchange (BEI) in 2016-2018.

\section{RESULTS AND DISCUSSION}

Testing data normality using the Kolmogorov Smirnov test with residual data criteria is said to be normal if the significant value is above 0.05 or $5 \%$. Data normality test results using the Kolmogorov Smirnov test showed that a significant value of $0.961>0.05(5 \%)$, the data can meet the normality criteria so that the residual model is declared normal. In this study, a multicollinearity test was measured by fulfilling the criteria that the VIF value was not more than ten, and the tolerance value was more than 0.10 . VIC multicollinearity test results $\leq 10$ for all independent variables, also with a tolerance value $\geq 0.10$. Thus it can be concluded that there is no multicollinearity between independent variables in the regression model. The test results show that the value of earnings tolerance is 0.649 , the value of cash flow tolerance is 0,683 , and the tolerance value of company size is 0.900 . The VIF value of earnings is 1.542 , the VIF value of cash flow is 1.464, and the VIF value of company size is 1.111. All variables used include earnings, cash flow, and company size have a tolerance value $\geq 0.10$, and a VIF value $\leq$ (Variance Inflation Factor $\leq 10$ means that the three variables do not occur multicollinearity, which means that all of these variables can be used as variables which are mutually independent. Heteroscedasticity test results in a sample of companies showed results ten and VIF value $\leq$ (Variance Inflation Factor) $\leq 10$ means that the three variables do not occur multicollinearity, which means that all of these variables can be used as mutually independent variables. Heteroscedasticity test results in a sample of companies showed results ten and VIF value $\leq$ (Variance Inflation Factor) $\leq 10$ means that the three variables do not occur multicollinearity, which means that all of these variables can be used as mutually independent variables. Heteroscedasticity test results in a sample of companies showed results where the scatterplot graph shows that the points spread on the Y-axis, so they don't produce a pattern. Thus it can be concluded that there is no heteroskedasticity in the regression model of this study. This study uses the Durbin Watson test criteria as an autocorrelation test method. The results of the autocorrelation test using the Durbin Watson test obtained Durbin Watson's value of 1.962. The criteria for testing autocorrelation in Durbin Watson values 1,962 are located between 1.7326 to 2.2674, which have the conclusion that the model does not experience autocorrelation or residual symptoms that have no relationship (correlation) with other observations arranged according to time series.

Multiple linear regression analysis is used in order to find out the formulation of the influence of the independent variables on the dependent variable. Based on the analysis results obtained formulation of multiple linear regression analysis models in this study as follows: $\mathrm{Y}=(1.473)+$ $(0.033 \mathrm{X} 1)+(1.305 \mathrm{X} 2)+(0.034 \mathrm{X} 3)$. The constant value in the regression equation above is 1.473 , which means that if all independent variables are considered constant, it will cause a change in financial distress of 1.473. The coefficient value of the earnings variable in the regression equation of 0.033 shows that if the value of the earnings variable increases by $1 \%$, assuming the other independent variables are constant, then the financial distress variable increases by 0.033 . The coefficient value of the cash flow variable in the regression equation of 1.305 shows that if the value of the variable cash flow increases by $1 \%$, assuming the other independent variables are constant, then the financial distress variable increases by 1.305 . The coefficient value of the firm size variable in the regression equation of 0.034 indicates that if the value of the firm size variable increases by $1 \%$, assuming the other independent variables are constant, then the financial distress variable increases by 0.034 .

Based on the results of the t-test (partial test), the $t$ value has a positive direction of 3.513 . While 
the value of t table looks at the table $\mathrm{t}$ probability or $\mathrm{df}=\mathrm{nkl}$ or $\mathrm{df}=96-3-1=92$ with significance $\alpha=0.05$, it can be seen the value of $t$ table $=1.986$. So the value of $t$ count $>t$ table or 3.513> 1.986. The Sig value of the profit variable in the table is 0.001 smaller than $\alpha=0.05$ or 0.001 $<0.05$, then $\mathrm{H} 1$ is accepted. The value of a positive t-test means that the variable $\mathrm{X} 1$ is in the same direction as the $\mathrm{Y}$ variable, so it can be concluded that earnings affect financial distress.

The income statement of a company will be listed as the company's achievement within a certain period. The higher profits generated by a company indicate that the company's performance is getting better so that the possibility of companies experiencing financial distress will be lower. Conversely, the lower profit shows that financial performance is not good, where the company is not able to optimize its resources to produce profits so that profits decline. This will give a negative signal to investors because the possibility of financial distress for the company will increase (Kusuma \& Sumani, 2017). High or low profit generated by a company shows the good or bad performance of the company in optimizing its resources so that it can signal the possibility of financial distress in the company. Concerning the financial conditions of a company will make a signal or an early warning for companies that they may experience financial distress.

Based on the results of the t-test (partial test), the $t$ value has a positive direction of 7.889 . While the value of $\mathrm{t}$ table looks at the table $\mathrm{t}$ probability or $\mathrm{df}=\mathrm{nkl}$ or $\mathrm{df}=96-3-1=92$ with significance $\alpha=0.05$, it can be seen the value of $t$ table $=1.986$. So the value of $t$ arithmetic $>t$ table or 7.889> 1.986. Sig value of cash flow variable in the table that is 0,000 is smaller than $\alpha=0.05$ or 0,000 $<0.05$ then $\mathrm{H} 2$ is accepted. The value of the positive t-test means that the $\mathrm{X} 2$ variable is in the same direction as the $\mathrm{Y}$ variable, so it can be concluded that cash flow affects financial distress. The cash flow statement is used by creditors to see a company's ability to pay off its debts. The higher the operating cash flow ratio calculated from the statement of cash flows, the lower the likelihood of financial distress due to a large number of cash shows that the company will be able to pay its obligations and the company is not experiencing financial distress, and vice versa (Frans) Julius, 2017). This cash flow is measured using the operating cash flow ratio, which is to compare the amount of cash flow from operating activities divided by the number of current liabilities where this ratio can show the ability of cash flow from operating activities of the company in paying current liabilities.

Based on the results of the t-test (partial test), the $t$ value was calculated to have a positive direction of 0.612 . While the value of $t$ table looks at the table $t$ probability or $\mathrm{df}=\mathrm{nkl}$ or $\mathrm{df}=96$ $3-1=92$ with significance $\alpha=0.05$, it can be seen the value of $\mathrm{t}$ table $=1.986$. So the value of $\mathrm{t}$ count $<\mathrm{t}$ table or $0.612<1.984$. Sig value of company size in the table that is 0.542 is greater than $\alpha=0.05$ or $0.542>0.05$ then H3 is rejected. The value of the positive t-test means that the X3 variable is not aligned with the Y variable, so it can be concluded that the size of the company has no effect on financial distress. The size of the company illustrates how big the total assets owned by the company, where if the company has a large number of total assets, the tendency of companies to experience financial distress becomes smaller and the company will be able to pay off its obligations (Putri and merkusiwati, 2014: 96). Although the size of large companies with large total assets is also inseparable from large risks such as economic risks, namely fluctuations in the exchange rate of the rupiah against the US dollar, interest rates, and inflation rates all have a major impact on the company's financial position and consumer purchasing power. So the company will continue to experience financial difficulties to pay off its debts when due. Although the size of large companies with large total assets is also inseparable from large risks such as economic risks, namely fluctuations in the exchange rate of the rupiah against the US dollar, interest rates, and inflation rates all have a major impact on the company's financial position and consumer purchasing power. So the company will continue to experience financial difficulties to pay off its debts when due. Although the size of large companies with large total assets is also inseparable from large risks such as economic risks, namely fluctuations in the exchange rate of the rupiah against the US dollar, interest rates, and inflation rates all have a major impact on the 
company's financial position and consumer purchasing power. So the company will continue to experience financial difficulties to pay off its debts when due.

The coefficient of determination (R2) aims to measure how far the model's ability to explain variations in the dependent variable. Determination efficiency test using Adjusted R square value. The results of the determination coefficient test on the adjusted R square value of 0.626 or $62.6 \%$. This value indicates that financial distress is influenced by earnings, cash flow, and company size by $62.6 \%$, while the rest is shown by a value of $€ 37.4 \%$, indicating that financial distress is influenced by other variables not examined in this study.

\section{CONCLUSION}

Based on the results of the analysis related to the effect of earnings, cash flow, and company size on financial distress in the manufacturing companies in the consumer goods industry sector in 2016-2018 can be concluded as follows: 1) earnings affect the financial stress because according to the research data obtained it can be seen that the higher the profit using the return on asset indicator is considered the higher the z-score so that the possibility of financial distress will be lower, and vice versa. High or low profit generated by a company shows the good or bad performance of the company in optimizing its resources so that it can signal the possibility of financial distress in the company. 2) Cash flow affects financial distress because, according to research data obtained, it can be seen that the higher the value of cash flow using the operating cash flow ratio indicator is considered with the higher value of z-score so that the possibility of financial distress will be lower, and vice versa. The cash flow statement is used by creditors to see a company's ability to pay off its debts. The higher the operating cash flow ratio, which is calculated from the cash flow statement, the lower the possibility of financial distress due to a large number of cash shows that the company will be able to pay its obligations, and the company is not experiencing financial distress, and vice versa. 3) The size of the company has no effect on financial distress because, according to the research data obtained, it can be seen that the greater the size of the company measured using total assets is not followed by the higher z-score, so it does not affect the likelihood of financial distress.

Although the size of large companies with large total assets is also inseparable from large risks such as economic risks, namely fluctuations in the exchange rate of the rupiah against the US dollar, interest rates, and inflation rates all have a major impact on the company's financial position and consumer purchasing power. So the company will continue to experience financial difficulties to pay off its debts when due.

Based on the results of the study and conclusions that have been obtained, researchers provide suggestions as follows: 1) For further research, it is better to add another variable as an independent variable because it can be possible there are still other variables that can affect financial distress. 2) Further research is expected that the sample data taken not only from consumer goods industry sector companies, but will be extended to other sector companies.

\section{REFERENCE}

Ghozali, I. (2016). Aplikasi analisis multivariate dengan program IBM SPSS 23 (Edisi 8). Cetakan ke VI Semarang : Badan Penerbit Universitas diponegoro. 
Julius, F. (2017). Pengaruh Financial Leverage, Firm Growth, Laba dan Arus Kas Terhadap Financial Distress (Studi Pada Perusahaan Manufaktur yang Terdaftar di BEI Tahun 20102014). JOM Fekon, 4(1), 1164-1178.

Kusuma, E., \& Sumani. (2017). Pengaruh Likuiditas, leverage dan Profitabilitas Terhadap Financial Distress (Z-Score) Perusahaan Property, Real Estate, dan Manufaktur Periode 2014-2016. Jurnal Manajemen, 14(1), 1-16.

Laksmita, N. (2016). Pengaruh Arus Kas dan Likuiditas Terhadap Financial Distress (Studi Kasus pada Peursahaan Sub Sektor Properti dan Real Estate yang Terdaftar di BEI Tahun 20112015). 1-19.

Natariasari, R., \& Indarto, M. (2014). Manfaat Laba dan Arus Kas untuk Memprediksi Kondisi Financial Distress (Studi pada Perusahaan Manufaktur di Bursa Efek Indonesia). Jurnal Sosial Ekonomi Pembangunan, 11, 152-173.

Paramita, R. W. D. (2012). Pengaruh Firm Size Terhadap Earnings Response Coeffisient (ERC) dengan Voluntary Disclosure Sebagai Variabel Intervening. Jurnal WIGA, 2(1), 64-78.

Paramita, R. W. D. (2012). Pengaruh Leverage, Firm Size, dan Voluntary Disclosure Terhadap Earnings Response Coefisient (ERC). Jurnal WIGA, 2(2), 103-118.

Paramita, R. W. D., \& Rizal, Noviansyah. (2018). Metode Penelitian Kuantitatif Buku ajar Perkuliahan Metodologi Penelitian Bagi Mahasiswa.Azyan Mitra Media. Yogyakarta.

Rahayu, W. P., \& Sopian, D. (2016). Pengaruh Rasio Keuangan dan Ukuran Perusahaan Terhadap Financial Distress (Studi Empiris Pada Perusahaan Food and Beverage di BEI). STIE STAN-IM, 1-13.

Setiawan, D., Oemar, A., \& Pranaditya, A. (2015). Pengaruh Laba, Arus Kas, Likuiditas Perusahaan, Ukuran Perusahaan, Leverage, Kepemilikan Institusional dan Kepemilikan Manajerial Untuk Memprediksi Kondisi Financial Distress (Pada Perusahaan Manufaktur Yang Terdapat di BEI Periode tahun 2010-2015). 1-15.

Wayan, N., Arwinda, K., Kt, N., \& Merkusiwati, L. A. (2014). Pengaruh Mekanisme Corporate Governance, Likuiditas, Leverage, dan Ukuran perusahaan Pada Financial Distress. EJurnal Akuntansi Universitas Udayana, 7(1), 93-106.

http://www.idx.co.id.

https://www.investindonesia.go.id/id/artikel-investasi/detail/perkembangan-industri-manufakturdi-indonesia 